\title{
Erratum: Nurses' views on promotion and the influence of race, class and gender in relation to the Employment Equity Act
}

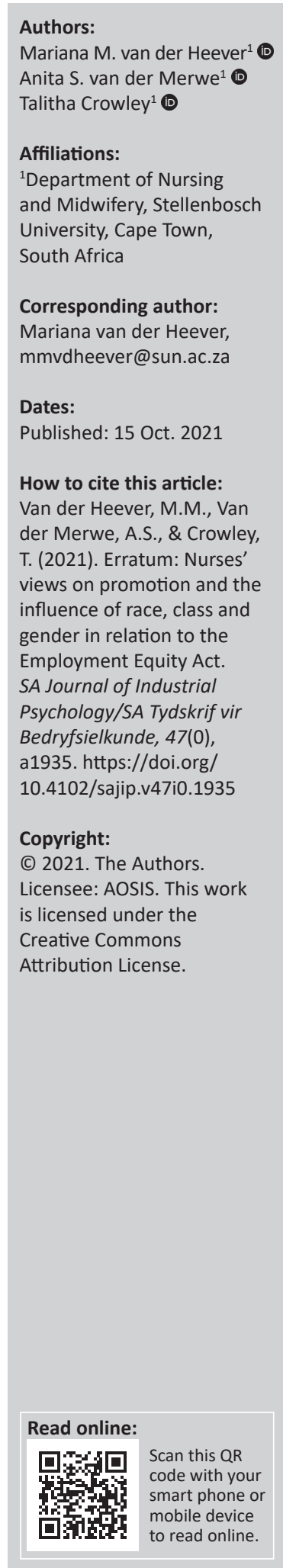

\section{Authors:}

Anita S. van der Merwe ${ }^{1}$ (D)

Talitha Crowley ${ }^{1}$ (D)

Affiliations:

University, Cape Town

South Africa

Corresponding author:

Mariana van der Heever,

Dates:

Published: 15 Oct. 2021

How to cite this article:

T. (2021). Erratum: Nurses' views on promotion and the gender in relation to the Employment Equity Act. SA Journal of Industrial Psychology/SA Tydskrif vir 1935. https://doi.org/

Copyright:

(C) 2021. The Authors.

Licensee: AOSIS. This work

is licensed under the

Creative Commons

Attribution License.
In the version of the article initially published, Van der Heever, M.M., Van der Merwe, A.S., \& Crowley, T. (2019). Nurses' views on promotion and the influence of race, class and gender in relation to the Employment Equity Act. SA Journal of Industrial Psychology/SA Tydskrif vir Bedryfsielkunde, 45(0), a1611. https://doi.org/10.4102/sajip.v45i0.1611, on page 11, under the 'Practical implications' section 'female nurses of colour' was incorrectly given as 'mixed race people'. The 'Practical implications' section is hereby updated:

\section{Practical implications}

As the results indicate the persistence of racial hierarchies in terms of positions held in the workplace and the inferior viewing of female nurses of colour, management should actively seek ways to enhance inclusivity. These should include diversity training, a racially diverse recruitment team and enhancing the transformational managerial skills of managers to minimise discontent among followers and increase unity among race groups. 